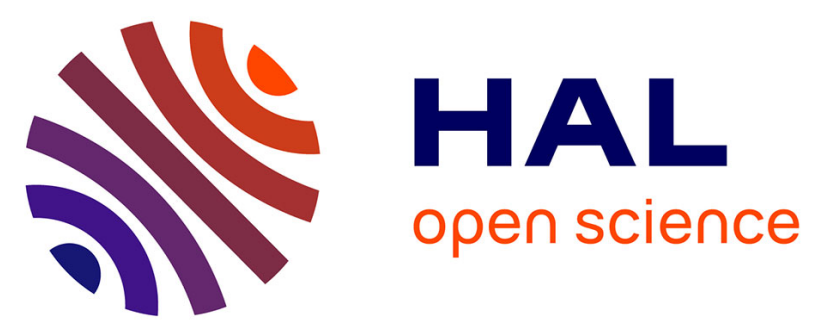

\title{
Nitrogen balance and irrigation water productivity for corn, sorghum and durum wheat under direct seeding into mulch when compared with conventional tillage in the southeastern France
}

\author{
M.R. Khaledian, J.C. Mailhol, P. Ruelle, I. Mubarak, F. Maraux
}

\section{To cite this version:}

M.R. Khaledian, J.C. Mailhol, P. Ruelle, I. Mubarak, F. Maraux. Nitrogen balance and irrigation water productivity for corn, sorghum and durum wheat under direct seeding into mulch when compared with conventional tillage in the southeastern France. Irrigation Science, 2011, 29 (5), 10 p. hal00575331

\section{HAL Id: hal-00575331 \\ https://hal.science/hal-00575331}

Submitted on 10 Mar 2011

HAL is a multi-disciplinary open access archive for the deposit and dissemination of scientific research documents, whether they are published or not. The documents may come from teaching and research institutions in France or abroad, or from public or private research centers.
L'archive ouverte pluridisciplinaire HAL, est destinée au dépôt et à la diffusion de documents scientifiques de niveau recherche, publiés ou non, émanant des établissements d'enseignement et de recherche français ou étrangers, des laboratoires publics ou privés. 


\title{
Nitrogen balance and irrigation water productivity for corn, sorghum and durum wheat under direct seeding into mulch as compared with conventional tillage in the Southeastern France
}

\author{
M.R. Khaledian ${ }^{1}$, J.C. Mailhol ${ }^{1}$, P. Ruelle ${ }^{1}$, I. Mubarak ${ }^{1}$, F. Maraux ${ }^{2}$ \\ 1) UMR G-EAU Cemagref, BP 5095, 34196 Montpellier Cedex 05 France \\ email: mohammad.khaledian@,cemagref.fr \\ 2) CIRAD, UR Systèmes de Culture Annuels, BP 5035, 34398 Montpellier Cedex 5 France
}

\begin{abstract}
Direct seeding into mulch (DSM) reduces soil evaporation. Therefore DSM can decrease the crop water demand. Furthermore DSM provides a favorable food source for soil microorganisms which can enhance the degradation of organic matter and improve nitrogen (N) availability for crops. Nowadays, a major challenge in irrigation is to increase irrigation water productivity (WP). This study assessed the impact of DSM on the N balance and WP according to experimental results compared with conventional tillage (CT). The results showed that DSM could mitigate N losses and improve WP for corn and sorghum. Because of field experimental limitations PILOTE, an operational model, was employed to test the hypothesis that DSM can be more efficient in water use. PILOTE was adapted and then calibrated and validated in the same experimental station. Taking into account the cover crop season, the model simulated the irrigation amount for a corn crop with a target yield of $14 \mathrm{t} / \mathrm{ha}$ during the long climatic series of 1991-2007. The results showed a WP increase from 77 with CT to $102 \mathrm{~kg} / \mathrm{mm}$ with DSM. DSM can improve WP and save a water application depth of 40 $\mathrm{mm}$ compared to $\mathrm{CT}$, which is interesting in a context with water scarcity.
\end{abstract}

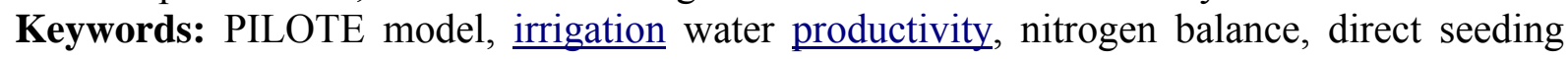
into mulch

\section{Introduction}

World food demand, and in other words agricultural water consumption, will continue to increase during the coming years. With a growing population, rising incomes, and changes in diets, food demand may grow by $70 \%-90 \%$ by 2050 . Without improvements in the efficiency of agricultural water use, crop water consumption would have to grow by the same order of magnitude (de Fraiture et al. 2007). Competition between water for food production and water for cities and the environment will intensify. In addition, climate change will increase pressures on water resources. Irrigation development assistance from major international donors has been on the decline over the years as a result of high capital costs, water scarcity, limited benefits to the poor rural communities and negative environmental impacts (Postel 1989). Thus more efforts are needed to save water.

Water is the most limiting factor for crop production in the Southeastern France due to the erratic distributions of annual rainfall. Therefore, it is essential to decrease irrigation demand while maintaining crop production. This can be obtained by improving irrigation water productivity (WP), to conserve water resource in this water-limited region. WP is usually defined as grain yield production per unit of irrigation water use (Viets 1962).

One possible solution can be direct seeding into mulch (DSM); according to FAO this system is characterized by minimum or zero soil tillage while maintaining high levels of previous crop residues on the soil surface. Mulch cover shields the soil from solar radiation thereby 
reducing evaporation from the soil (Holland 2004). The evaporation demand is mitigated because the warming of the soil is lesser. There is a major effect on the conservation of water by reducing runoff and evaporation losses in DSM. Therefore, more water is retained in the soil, where it remains potentially available for crop growth consequently decreasing irrigation demand (Kalra et al. 1984; Bussière and Cellier 1994; Gonzalez-Sosa et al. 1999; Dahiya et al. 2007; Govaerts et al. 2007). Increasing the productivity of irrigation water in agriculture is a way to address water scarcity issue. Therefore DSM is able to increase the productivity of irrigation water.

DSM provides a favorable food source for soil microorganisms which can enhance the degradation of organic matter, ended up in mineralization of $\mathrm{N}$ (Campbell et al. 1993; Mary et al. 1996; Schroth et al. 2001) being essential for crop production. The dynamics of soil N mineralization-immobilization are affected by the presence and placement of crop residues (Creus et al. 1998). When DSM is used, the profile of soil nutrient distribution is modified (Unger 1991). The soil mineral $\mathrm{N}$ distribution in the upper part of the soil profile is altered (Franzluebbers et al. 1995) and the availability of N improves in a few years (Rice et al. 1986; Angás et al. 2006).

Despite of the potential benefits of DSM system from an environmental and economical point of view and the possibility of its application in most of the European countries; the evolution of conservation agriculture has been slower in European Union than in other parts of the world. At beginning (1970s) the introduction of conservation tillage in Europe was mainly driven by economic considerations (Lahmar 2008). But nowadays, regarding Europe, the 2003 and 2005 drought events, especially in France and Spain, soil erosion and climate change definitely confirm the urgent need for the implementation of common strategies to address the issues.

However DSM is a well-known system especially in the large mechanized farms of Northern and Southern America, but the impacts of this system in the Mediterranean climate especially in the Southeastern France is less known. Despite of early interest in DSM, there still are few synthetic reviews of the research findings (Cannel 1985; Soane and Ball 1998; Rasmussen 1999; Tebrügge and Düring 1999; Deumlich et al. 2006; Bertocco et al. 2008) and the utilization of DSM by European farmers is still very weak compared to America and Australia (Derpsch 2005; Lahmar 2008). According to De Vita et al. (2007) the long-term effects of conventional tillage (CT) and no-tillage, under Mediterranean conditions have scarcely been studied. Especially there is little information available in the literature concerning the effects of tillage systems on the $\mathrm{N}$ balance and WP of corn, sorghum and durum wheat especially in the Southeastern France, located in the Mediterranean context. In this context, different conservation tillage systems are not familiar for almost of farmers and they do not have enough technical information to adopt these systems. Therefore it is not used in so many of field area. As part of a continuing study program of DSM in the Southeast of France, the study reported here has been designed to understand the impacts of DSM on the N balance and the WP as compared with CT. Results may contribute to design alternatives to $\mathrm{CT}$ systems in the context of water scarcity.

\section{Material and methods}

- Experimental description

An experimental study has been carried out to compare the $\mathrm{N}$ balance and WP of corn (Samsara variety in 2001 and 2002, and Pioneer PR35Y65 variety in 2007), sorghum (Argence variety) and durum wheat (Artimond variety in 2004/05 and Dakter variety in 2005/06) with DSM compared with CT. This study was conducted at Lavalette experimental 
site of the Cemagref Institute $\left(43^{\circ} 40^{\prime} \mathrm{N}, 3^{\circ} 50^{\prime} \mathrm{E}\right.$, altitude $30 \mathrm{~m}$ ) which is located in Montpellier in the Southeastern France, $15 \mathrm{~km} \mathrm{~N}$ of Mediterranean Sea. The average annual rainfall is of $780 \mathrm{~mm} /$ year (an 18-year average). Annual evapotranspiration calculated by Penman equation exceeds annual rainfall under this Mediterranean climate $(870 \mathrm{~mm} /$ year$)$. Those climate data were monitored at the weather station located in the experimental station. Some measured soil physical and chemical properties are given in Table 1.

Soil of CT and DSM plots is loamy. Soil of CT has 18, 47 and 35\% of clay, silt and sand, respectively. Soil of DSM has 17,39 and 44\% of clay, silt and sand, respectively. Some measured soil physical and chemical properties are given in Table 2.

Table 1. Average monthly climatic data, Lavalette meteorological station (1991-2007)

\begin{tabular}{lllllllllllll}
\hline & Jan & Feb & Mar & Apr & May & Jun & Jul & Aug & Sep & Oct & Nov & Dec \\
\hline $\begin{array}{l}\text { Maximum } \\
\text { temperature, }{ }^{\circ} \mathrm{C}\end{array}$ & 12 & 14 & 17 & 19 & 23 & 28 & 31 & 30 & 25 & 21 & 16 & 13 \\
$\begin{array}{l}\text { Minimum } \\
\text { temperature, }{ }^{\circ} \mathrm{C}\end{array}$ & 2 & 1 & 4 & 7 & 11 & 14 & 16 & 17 & 13 & 11 & 5 & 2 \\
$\begin{array}{l}\text { ETo, mm } \\
\text { Precipitation, mm }\end{array}$ & 12 & 27 & 57 & 86 & 122 & 153 & 108 & 141 & 84 & 42 & 18 & 9 \\
\hline
\end{tabular}

Table 2. Soil physical and chemical properties at Lavalette in 2007 (after 7 years of DSM)

\begin{tabular}{lccclllll}
\hline Plot & clay & silt & sand & texture (USDA) & $\begin{array}{l}\text { organic } \\
\text { matter } \\
(\%)\end{array}$ & $\begin{array}{l}\text { organic } \\
\text { carbon } \\
(\%)\end{array}$ & $\begin{array}{l}\mathrm{N} \text { total } \\
(\%)\end{array}$ & $\mathrm{C} / \mathrm{N}$ \\
\hline $\mathrm{CT}$ & 18 & 47 & 35 & loam & 1.34 & 0.78 & 0.08 & 10 \\
DSM & 17 & 39 & 44 & loam & 1.79 & 1.04 & 0.09 & 11.81 \\
\hline
\end{tabular}

Besides texture, other soil properties presented here are for $0-30 \mathrm{~cm}$ layer.

In DSM plots, crop and cover crop sowing was performed with the specific direct seeder. Each season the cover crop in DSM system was destroyed by glyphosate approximately two weeks before the sowing of the main crop in DSM. The crop rotation in the form of cover crop in DSM as well as the main crop in both CT and DSM is presented in Table 3. After a 4year study, durum wheat was sown for two successive cropping seasons (2004/05 and 2005/06) after the summer corn and sorghum. There were enough residues on the soil surface (1-2.5 t/ha) to form a mulch at the time of sowing. During September 2005, there was a flood between the harvest of durum wheat (2004/05) and the sowing of durum wheat (2005/06); consequently we could not install a cover crop too.

Table 3. The crop rotation at Lavalette

\begin{tabular}{lll}
\hline Season & cover crop in DSM & main crop in CT and DSM \\
\hline $2000 / 01$ & oat $^{1}$ & corn $^{2}$ \\
$2001 / 02$ & oat & corn \\
$2002 / 03$ & durum wheat & sorghum \\
$2003 / 04$ & mix of oat and vetch & sorghum \\
$2004 / 05$ & sorghum residue & durum wheat \\
$2005 / 06$ & durum wheat residue & durum wheat \\
$2006 / 07$ & mix of oat, vetch and rape ${ }^{6}$ & corn \\
${ }^{1}$ Avena sativa L., ${ }^{2}$ Zea mays L., ${ }^{3}$ Triticum turgidum L. var durum., ${ }^{4}$ Sorghum bicolor L. Moench, ${ }^{5}$ Vicia sativa \\
${ }_{\text {L., }}{ }^{6}$ Brassica napus L.
\end{tabular}


In CT plots, disc harrow, plough, harrow, and seeder were used in the tillage sequence. Primary tillage with disc harrow was done to chop and bury the residues. Secondary tillage with plough was performed afterwards. Depth of the tillage was $25 \mathrm{~cm}$ in average. By using a harrow, seedbed was prepared and crop sowing was performed by a classic seeder.

The agricultural practices and the use of plant protection agents were in accordance with local practices, official recommendations and expert advice. The goal was to mimic as close as possible the conditions of production in commercial farms. So that, farm scale equipment were fixed and repeated during the experiment period. Tillage, sowing and harvest dates for corn, sorghum and durum wheat with CT and DSM are presented in Table 4.

Table 4. Tillage, sowing and harvest dates as well as $\mathrm{N}$ application $(\mathrm{kg} / \mathrm{ha})$ for corn (Samsara variety) in 2001 and 2002, sorghum (Argence variety), durum wheat (Artimond variety) in 2004/05, durum wheat (Dakter variety) in 2005/06 and corn (Pioneer PR35Y65 variety) in 2007 with conventional tillage (CT) and direct seeding into mulch (DSM)

\begin{tabular}{llllll}
\hline Season & treatment & tillage date & sowing date & harvest date & $\begin{array}{l}\text { N } \\
\text { application }\end{array}$ \\
\hline 2001/corn & CT & $12 / 10 / 2000$ & $5 / 2 / 2001$ & $9 / 10 / 2001$ & 120 \\
& DSM & - & $5 / 4 / 2001$ & $9 / 10 / 2001$ & 126 \\
\hline $2002 /$ corn & CT & $1 / 6 / 2002$ & $5 / 17 / 2002$ & $9 / 18 / 2002$ & 190 \\
& DSM & - & $5 / 17 / 2002$ & $9 / 24 / 2002$ & 173 \\
\hline $2003 /$ sorghum & CT & $1 / 15 / 2003$ & $5 / 10 / 2003$ & $9 / 17 / 2003$ & 64 \\
& DSM & - & $5 / 7 / 2003$ & $9 / 12 / 2003$ & 87 \\
\hline 2004/sorghum & CT & $1 / 8 / 2004$ & $5 / 9 / 2004$ & $9 / 13 / 2004$ & 137 \\
& DSM & - & $5 / 7 / 2004$ & $9 / 24 / 2004$ & 100 \\
\hline 2004-05/durum & CT & $9 / 30 / 2004$ & $11 / 17 / 2004$ & $6 / 28 / 2005$ & 151 \\
wheat & DSM & - & $11 / 30 / 2004$ & $7 / 5 / 2005$ & 121 \\
\hline 2005-06/durum & CT & $10 / 07 / 2005$ & $11 / 23 / 2005$ & $06 / 28 / 2006$ & 160 \\
wheat & DSM & - & $11 / 29 / 2005$ & $06 / 28 / 2006$ & 140 \\
\hline 2007/corn & CT & $11 / 15 / 2006$ & $4 / 24 / 2007$ & $9 / 28 / 2007$ & 180 \\
& DSM & - & $4 / 24 / 2007$ & $9 / 28 / 2007$ & 180 \\
\hline
\end{tabular}

Table 5 represents the cover crop types and the mulch quantity they produced in DSM from 2001 to 2007.

Table 5. Cover crop and produced mulch at sowing of main crop from 2001 to 2007 in DSM

\begin{tabular}{llll}
\hline Season & cover crop & $\begin{array}{l}\text { residues from precedent } \\
\text { crops at sowing }(\mathrm{Mg} / \mathrm{ha})\end{array}$ & $\begin{array}{l}\text { mulch produced by } \\
\text { cover crop }(\mathrm{Mg} / \mathrm{ha})\end{array}$ \\
\hline 2001 & oat & 1.7 & 3.29 \\
2002 & oat & 2.5 & 4.5 \\
2003 & durum wheat & 3 & 0.4 \\
2004 & mix of oat and vetch & 1.7 & 4.35 \\
2005 & sorghum residue & 2.5 & - \\
2006 & durum wheat residue & 1 & - \\
2007 & mix of oat, vetch and rape & 0.5 & 8 \\
\hline
\end{tabular}




\section{- Nitrogen balance}

Soil mineral $\mathrm{N}$ content was determined before sowing (for durum wheat at the beginning of March) and after harvest. The dates of sowing and harvest are presented in Table 3. Seven core samples per plot were taken from 0-10, 10-30, 30-60, 60-90, 90-120, and 120-150 cm depths with an auger. Then the samples of each layer were mixed and sieved to have a representative and unique sample for each layer. Plant $\mathrm{N}$ content i.e. in leaves, stems and

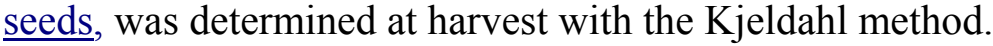

In our study, we used the simple method which was presented by Angás et al. (2006) to assess the $\mathrm{N}$ balance in both systems. $\mathrm{N}$ mineralization $\left(\mathrm{N}_{\mathrm{Min}}\right)$ was estimated using the equation (1) proposed by Sexton et al. (1996) in zero $\mathrm{N}$ application plots $(0 \mathrm{~N})$ :

$\mathrm{N}_{\mathrm{Min}}=\mathrm{N}_{\mathrm{F}}-\mathrm{N}_{\mathrm{I}}+\mathrm{N}_{\mathrm{P}}+\mathrm{N}_{\mathrm{MF}}-\mathrm{N}_{\mathrm{MI}}$

, where $\mathrm{N}_{\mathrm{I}}$ and $\mathrm{N}_{\mathrm{F}}$ are the soil $\mathrm{N}$ contents at the beginning and at the end of study period, respectively. $\mathrm{N}_{P}$ is the $\mathrm{N}$ uptake by plant. $\mathrm{N}_{\mathrm{MI}}$ and $\mathrm{N}_{\mathrm{MF}}$ are mulch $\mathrm{N}$ content at the beginning and at the end of study period, respectively. In CT, $\mathrm{N}_{\mathrm{MF}}$ and $\mathrm{N}_{\mathrm{MI}}$ were not considered.

This method assumes that there is no loss of $\mathrm{N}$ in treatments because there is no drainage as attested by the tensiometer monitoring over the study period. There was not any runoff too. Leaching and volatilization of $\mathrm{N}$ as well as the $\mathrm{N}$ of rainfall and irrigation water were not considered in the $\mathrm{N}$ balance (Nemeth 2001).

Losses of $\mathrm{N}$ in the fertilized plots (P) have been deducted from the balance between $\mathrm{N}_{\mathrm{Min}}, \mathrm{N}_{\mathrm{I}}$, $\mathrm{N}_{\mathrm{F}}, \mathrm{N}_{\mathrm{P}}, \mathrm{N}_{\mathrm{MF}}, \mathrm{N}_{\mathrm{MI}}$ as defined above and $\mathrm{N}_{\mathrm{Ap}}(\mathrm{N}$ fertilizer applied):

$\mathrm{P}=\mathrm{N}_{\mathrm{F}}-\mathrm{N}_{\mathrm{I}}+\mathrm{N}_{\mathrm{P}}-\mathrm{N}_{\mathrm{Ap}}-\mathrm{N}_{\mathrm{Min}}+\mathrm{N}_{\mathrm{MF}}-\mathrm{N}_{\mathrm{MI}}$

A negative value of $\mathrm{P}$ is interpreted as a loss of $\mathrm{N}$ in the soil-plant system.

\section{- Water productivity}

Generally, WP is defined in agronomy (Viets 1962) as:

$\underline{\mathrm{WP}}=\frac{\text { yield }}{\text { water used to produce the yield }}$

According to Rodrigues and Pereira (2009) the concept of water productivity to more consistently discriminate the role of irrigation in crop production can be rewritten as:

$\underline{\mathrm{WP}}=\frac{\text { yield }}{\text { irrigation }}$

, where yield is grain yield in $\mathrm{kg} / \mathrm{ha}$ and irrigation is irrigation water depth in $\mathrm{mm} / \mathrm{ha}$; so WP will be in $\mathrm{kg} / \mathrm{mm}$.

\section{- Model description}

PILOTE is an operational model based on the leaf area index (LAI) simulation (Mailhol et al. 1997 and 2004) which simulates water balance and yield. It simulates the soil water reserve (SWR) evolution at a daily time step. SWR refers to three reservoirs. The first one has a 10 
cm depth while the others vary with root development. In DSM, the mulch effect limits soil evaporation and creates a microclimate in the case of consecutive irrigations or rainfalls. In the modified version of PILOTE (Khaledian et al. 2009) these new conditions were taken into account especially by introducing a coefficient to reduce soil evaporation $\left(\mathrm{X}_{\mathrm{sr}}\right)$ and by reducing $\mathrm{K}_{\mathrm{cmax}}$ for corn from 1.2 to 1.1 to account for the modified microclimate conditions. Our modeling approach consisted of a simple quantitative description of surface residue impact on the water balance, requiring limited data inputs. That is in contrast with other published more detailed, physically based, mulch models that quantify surface residue impact on soil water content by solving the balance of energy and water at the soil surface (Ross et al. 1985; Bussiere and Cellier 1994; Findeling et al. 2003). Parameterization of such models to address practical problems remains difficult due to the measurement of necessary parameters being not available for a wide range of conditions. Moreover a large number of these parameters related to the physical properties of the mulch layer may change considerably over the season due to mulch decomposition. $\mathrm{X}_{\mathrm{sr}}$, our single parameter related to mulch quantity on the soil surface has a direct influence on the soil water balance. Other relationships describing mulch impacts were not incorporated in PILOTE model (Khaledian et al. 2009) to retain model simple and easy to calibrate in different environments. So, soil evaporation $\left(E_{s}\right)$ assumed to only affect the shallow reservoir, is calculated according to:

$\mathrm{E}_{\mathrm{s}}=\frac{E T_{0} \exp (-\varepsilon L A I)}{1+X_{s r}}$

, where $\mathrm{ET}_{0}$ is the reference evapotranspiration, $\varepsilon$ is the extinction coefficient for net radiation in the crop canopy layer (being 0.7), $\mathrm{X}_{\mathrm{sr}}$ is an empirical parameter that could be linked to the quantity of mulch on the soil surface $\left(0 \leq \mathrm{X}_{\mathrm{sr}} \leq 1 ; \mathrm{X}_{\mathrm{sr}}=0\right.$ in $\mathrm{CT}$ system $)$. Indeed, this modification was initiated by the approach experimentally deduced by Gusev (2002) where a hyperbolic decrease of $\mathrm{E}_{\mathrm{s}}$ vs. mulch accumulation $\left(\mathrm{MA}, \mathrm{Mg} / \mathrm{ha}\right.$ ) was found. Although $\mathrm{E}_{\mathrm{s}}$ estimation proposed by Eq. (5) is empirical, a physical meaning can be proposed to $\mathrm{X}_{\mathrm{sr}}$ (see Khaledian et al. 2009) when comparing with the Scopel approach (Scopel et al. 2004). They used a mulch area index which varies over the crop season (variation not easily predictable), in contrast with PILOTE.

The previous developments attest that an experimental approach could be used to establish a robust link between $\mathrm{X}_{\mathrm{sr}}$ and the mulch quantity. In our modeling approach, $\mathrm{X}_{\mathrm{sr}}$ is derived from model calibration by a classical trial and errors approach. The effort of calibration focuses on a period where its sensitivity on the water balance estimation is the highest. This period is the beginning of the cropping season (from sowing to $\mathrm{LAI}<3$ ) where LAI is low and, consequently, soil evaporation is presumed to be high especially for summer crops e.g. corn crop.

The root mean squared error (RMSE) and the prediction efficiency of model (PE, Nash and Sutcliffe 1970) were used to evaluate grain yield (GY) and SWR simulations.

$$
\begin{aligned}
& \mathrm{RMSE}=\sqrt{\frac{\sum_{i=1}^{n}\left(M_{i}-S_{i}\right)^{2}}{n}} \\
& \underline{\mathrm{PE}}=1.0-\frac{\sum_{i=1}^{n}\left(M_{i}-S_{i}\right)^{2}}{\sum_{i=1}^{n}\left(M_{i}-M_{a v g}\right)^{2}}
\end{aligned}
$$


, where $M_{i}$ is the ith measured value, $S_{i}$ is the ith simulated value, $M_{\text {avg }}$ is the average of measured values, and $\mathrm{n}$ is the number of data pairs. The same criteria were used to evaluate SWR simulations during the cover crop season.

The experimental limitations did not allow us to test different scenarios of water supply on both DSM and CT systems, to check the potential of DSM regarding WP compared with CT. Hence, we used the PILOTE model (Khaledian et al. 2009) for corn case in both systems. As we need to initialize the SWR at sowing for simulating the irrigation demand and the yield of the main crop (corn) we must first ensure that the model satisfactorily simulates SWR during the cover crop season. After verification, we can apply this model on a climatic series to analyze the benefits of adopting DSM rather than CT regarding water saving.

According to the current DSM practice in the Southeastern of France, the cover crop is set up between the harvest and the sowing of the main crop. After the harvest of durum wheat under DSM in 2006, a mixture of vetch, oat and rape was sown in mid-October. This cover crop has been destroyed before planting a corn crop in 2007 by glyphosate. During this period, SWR was monitored using Campbell ${ }^{\circledR}$ FDR CS615 sensor (for 0-30 cm) and neutron probe (for 0$120 \mathrm{~cm}$ ). To simulate the LAI of the composite cover crop, we have assumed that it has an evolution comparable to that of wheat; this appears consistent with observations, oat being the crop which was by far the most developed in the mixture as a result of seeding conditions and climate.

We intended therefore, using the PILOTE model to compare the irrigation need and the yield of DSM compared with CT. We perform simulations on a climatic series, available at Lavalette from 1991 to 2007 for the case of corn (Pioneer PR35Y65 variety). PILOTE model defines the timing of irrigation and the given doses. The irrigation strategy adopted aims to obtain an average yield of $14 \mathrm{Mg} / \mathrm{ha}$, below the potential yield (close to $18 \mathrm{Mg} / \mathrm{ha}$ ) to be realist in our context. The $\mathrm{X}_{\mathrm{sr}}$ coefficient of soil evaporation reduction, introduced for DSM case, is set at 0.5 according to the quantity of mulch on the soil surface (Khaledian et al. 2009). In DSM, the crop management consists of the sowing of a cover crop such as that adopted in 2006/07, which was destroyed, using an herbicide i.e. glyphosate, on March 15 or twenty days before planting the main crop.

\section{- Statistical treatment}

DSM and CT treatments were arranged in a complete randomized design replicated 5 times. Results were analyzed with ANOVA using Fischer's protected least significant at $\mathrm{P}<0.05$ as did De Vita et al. (2007).

\section{Results and discussion}

A better soil water and nutrient storage in DSM led us to hypothesize that in the Mediterranean climate with water scarcity and erratic rainfall, DSM would have a better N balance and WP compared with CT. This hypothesis has been assessed in our study.

\section{- Nitrogen balance}

Table 6 represents the soil $\mathrm{N}$ content at sowing and harvest, $\mathrm{N}$ application, mineralization rate, plant $\mathrm{N}$ uptake, the changes of $\mathrm{N}$ stored in mulch from sowing to harvest and finally the calculated $\mathrm{N}$ losses (data were not recorded in 2007).

During 2001-2004, when there were cover crops before sowing the main crop, the soil $\mathrm{N}$ content at sowing was lower in DSM compared with CT, except of 2003. This is due to the 
fact that the cover crop uptakes the residual soil $\mathrm{N}$. This phenomenon can be helpful when we want to decrease residual $\mathrm{N}$ leaching. Crop residues retention at the soil surface can influence nutrient cycling, because contact between soil microorganisms and residues is reduced, the soil surface microclimate is less favorable for residue decomposition than in soil and the residues have a tendency to decompose more slowly. It means that the nutrients in residues are released slowly, which reduces the amount of nutrients readily available for the crop in a given season (Malhi et al., 2001). In our study as the microorganisms decomposed the mulch and released $\mathrm{N}$ in the late part of the season, the soil $\mathrm{N}$ content at harvest was higher with DSM from 2003 to 2006 (data not shown). As the majority of $\mathrm{N}$ was released late in the season, when the crop has not a considerable $\mathrm{N}$ demand, an important part of released $\mathrm{N}$ remained in the soil. So, sowing a cover crop is an appropriate decision in this case afterwards the harvest to uptake soil N residual. According to Scopel (1994), DSM can find equilibrium after some years to feed satisfactorily the crop even at the beginning of the season. With DSM, $\mathrm{N}$ uptake by plant was lower for corn and durum wheat, whereas it was higher for sorghum as compared with CT. Montemurro et al. (2006) have shown a linear relationship $\left(\mathrm{R}^{2}=0.55\right)$ between the soil $\mathrm{N}$ content at sowing and the corn yield. They found that corn absorbed $40 \%$ of its necessary $\mathrm{N}$ from sowing to anthesis. In our study, the soil $\mathrm{N}$ content at sowing was low because of cover crop $\mathrm{N}$ consumption; so the major part of $\mathrm{N}$ releasing by mulch especially late in the season remained in the soil (Table 5). The preanthesis $\mathrm{N}$ uptake is important especially when the weather is hot and dry after anthesis. Higher temperature and lower rainfall strongly affect the process of uptake and translocation (Montemurro et al. 2006). The rate of mineralization was found to be approximately $0.75 \mathrm{~kg} \mathrm{~N} / \mathrm{ha} / \mathrm{day}$. This value is consistent with both the value obtained in the previous campaigns in the same field (Nemeth 2001, for the 1997-99 study period) and the values given in the literature (Paustian et al. 1990; Delin and Lindén 2002). The mineralization rate was lower with DSM than with CT. The same finding was reported by Nyborg and Malhi (1989). In DSM, the accumulation of biomass on the soil surface reduces soil evaporation. This may slow down soil drying process and maintain soil temperature lower, which delays and slows the mineralization and nitrification. In this context, there is a large population of microorganisms of soil capable to promote denitrification and activate anaerobic metabolism (Doran 1980; Rice and Smith 1982; Aulakh et al. 1984; Linn and Doran 1984). The cover crops produce a large biomass quantity on the soil surface, which is not exported. The tillage is generally used to incorporate this biomass in the soil, which accelerates the mineralization rate. Thus, DSM limits the rate of decomposition of organic matter, which is especially important in hot and humid climates where the rate of decomposition is very high. However, compared to the generic mineralization processes of organic matter, it is necessary to analyze the modifications introduced by DSM system. While the absence of tillage reduces the rate of mineralization, the presence of the cover crop may have an opposite effect. Indeed, the accumulation of organic residues on the surface increases soil biological activity, which intensifies the process of mineralization as in 2004 for example (Table 6).

The plant $\mathrm{N}$ uptake was found to be lower in DSM (except of 2003). This can be due to a lower plant population and consequently a lower N demand in DSM (data not shown).

For the first three years, the losses from CT and DSM were more or less equivalent but for the next three years the $\mathrm{N}$ losses from DSM were remarkably lower, being interesting in the term of environmental protection. Clearly the findings indicate that in our experimental conditions, DSM has a positive effect to reduce $\mathrm{N}$ losses. It appears that the suppression of soil operation and lower N application in DSM (in 2004/05 and 2005/06) resulted in substantial decreases in $\mathrm{N}$ losses. Our results are consistent with those of Bhagat and Verma (1991) who found that the presence of mulch can decrease fertilizer losses especially by volatilization. 
Table 6. Soil $\mathrm{N}$ content at sowing $\left(\mathrm{N}_{\mathrm{I}}\right)$ and at harvest $\left(\mathrm{N}_{\mathrm{F}}\right)$ in $0-150 \mathrm{~cm}, \mathrm{~N}$ application $\left(\mathrm{N}_{\mathrm{Ap}}\right), \mathrm{N}$ mineralization $\left(\mathrm{N}_{\mathrm{Min}}\right)$, plant $\mathrm{N}$ uptake $\left(\mathrm{N}_{\mathrm{P}}\right)$, mulch $\mathrm{N}$ changes from sowing to harvest $\left(\mathrm{N}_{\mathrm{M}}\right)$ and $\mathrm{N}$ losses, from 2001 to 2006 with both conventional tillage (CT) and direct seeding into mulch (DSM; all in kg/ha)

\begin{tabular}{lllllllll}
\hline Season/crop & treatment & $\mathrm{N}_{\mathrm{I}}$ & $\mathrm{N}_{\mathrm{F}}$ & $\mathrm{N}_{\mathrm{Ap}}$ & $\mathrm{N}_{\text {Min }}$ & $\mathrm{N}_{\mathrm{P}}$ & $\mathrm{N}_{\mathrm{M}}$ & N losses \\
\hline 2001/Corn & CT & 152 & 128 & 120 & 80 & 190 & - & 34 \\
& DSM & 101 & 124 & 126 & 60 & 134 & 18 & 47 \\
\hline 2002/Corn & CT & 91 & 77 & 190 & 72 & 207 & - & 69 \\
& DSM & 58 & 60 & 173 & 50 & 171 & 17 & 67 \\
\hline 2003/Sorghum & CT & 80 & 48 & 64 & 75 & 117 & - & 54 \\
& DSM & 102 & 59 & 87 & 58 & 146 & 9 & 51 \\
\hline 2004/Sorghum & CT & 92 & 45 & 137 & 70 & 174 & - & 80 \\
& DSM & 80 & 106 & 100 & 80 & 255 & 104 & 3 \\
\hline 2004-05/durum & CT & 73 & 77 & 151 & 84 & 134 & - & 97 \\
wheat & DSM & 111 & 200 & 121 & 79 & 120 & 10 & 1 \\
\hline 2005-06/durum & CT & 57 & 85 & 160 & 93 & 143 & - & 82 \\
wheat & DSM & 64 & 140 & 140 & 68 & 141 & 11 & 2 \\
\hline
\end{tabular}

The dry spring of 2005 after a relatively cold winter limited the mineralization. For DSM, $\mathrm{N}_{\mathrm{F}}$ increased because $\mathrm{N}$ fertilizer was partly immobilized by organic matter. In this condition, the calculation showed a loss of $\mathrm{N}$ considerably lower than that of CT treatment. It is likely that crop residues have blocked a part of fertilizer.

For 2005/06 season, first there was a sharp drop of soil $\mathrm{N}$ content at the end of winter compared to the values at harvest of the previous season (CT: $57 \mathrm{vs} .77 \mathrm{~kg}$ N/ha and DSM: 64 vs. $200 \mathrm{~kg} \mathrm{~N} / \mathrm{ha}$, see Table 6). N leaching was due to a flood that submerged more or less depending on the topography of the different parts of the field. For plant N uptake in DSM, it was close to that of CT who had a higher plant population (264 with CT vs. 201 plants $/ \mathrm{m}^{2}$ with DSM). In DSM, the mineralization was low and much lower than that of CT, contrary to what one might expect. In fact during the flood, crop residues in DSM moved out from the field. Accordingly, there remained little for organic matter mineralization, whereas in CT residues were incorporated into the soil.

\section{- Experimental irrigation water productivity}

Table 7 summarizes the GY and WP of corn, sorghum and durum wheat as well as irrigation and rainfall from 2001 to 2007. During the whole trial period the DSM GY were lower than CT GY. Statistically, except of the first season which was the season of DSM installation, the GY of corn and sorghum were not significantly different from those of CT. For durum wheat the grain yield was significantly lower with DSM, because of a lower plant population (84 in DSM vs. 264 plants $/ \mathrm{m}^{2}$ in CT) and cereal leaf beetle attack.

Except of the first season and the two seasons of durum wheat, WP was higher with DSM; however except of 2003 the differences were not significant. Lower WP of durum wheat with DSM was related to a lower grain yield as explained above. For 2003 season with a lower irrigation amount (68 in DSM vs. $123 \mathrm{~mm}$ in CT) DSM had a significantly higher WP which demonstrates the potential of DSM to improve WP.

In DSM not only there is a thick layer of mulch on the soil surface but also there is a micro climate being more humid in DSM than CT. These two factors result in decreasing soil evaporation or in other words actual evapotranspiration. But it is not evident that all of this 
saved water being beneficent to produce more total dry matter and GY due to crop production limitations i.e. lower plant population, plant $\mathrm{N}$ uptake, the presence of pests, irrigation timing, etc.

Table 7. Grain yield (GY), irrigation, rainfall, and water productivity (WP) from 2001 to 2007 seasons with conventional tillage (CT) and direct seeding into mulch (DSM)

\begin{tabular}{llllll}
\hline Season/crop & treatment & $\begin{array}{l}\text { GY } \\
(\mathrm{Mg} / \mathrm{ha})\end{array}$ & $\begin{array}{l}\text { irrigation } \\
(\mathrm{mm})\end{array}$ & $\begin{array}{l}\text { rainfall } \\
(\mathrm{mm})\end{array}$ & $\begin{array}{l}\underline{\mathrm{WP}} \\
(\mathrm{kg} / \mathrm{mm})\end{array}$ \\
\hline $2001 /$ corn & $\mathrm{CT}$ & $10.9 \mathrm{a}$ & 206 & 141 & $53 \mathrm{a}$ \\
& $\mathrm{DSM}$ & $7.95 \mathrm{~b}$ & 216 & 141 & $37 \mathrm{~b}$ \\
\hline $2002 /$ corn & $\mathrm{CT}$ & $11.9 \mathrm{a}$ & 346 & 311 & $34 \mathrm{a}$ \\
& $\mathrm{DSM}$ & $10.68 \mathrm{a}$ & 292 & 311 & $37 \mathrm{a}$ \\
\hline $2003 /$ sorghum & $\mathrm{CT}$ & $7.12 \mathrm{a}$ & 123 & 99 & $58 \mathrm{a}$ \\
& DSM & $6.71 \mathrm{a}$ & 68 & 109 & $99 \mathrm{~b}$ \\
\hline $2004 /$ sorghum & CT & $8.12 \mathrm{a}$ & 289 & 133 & $28 \mathrm{a}$ \\
& DSM & $8.52 \mathrm{a}$ & 276 & 133 & $31 \mathrm{a}$ \\
\hline $2004-05 /$ durum wheat & CT & $6.3 \mathrm{a}$ & 50 & 229 & $126 \mathrm{a}$ \\
& DSM & $3.1 \mathrm{~b}$ & 36 & 224 & $86 \mathrm{~b}$ \\
\hline $2005-06 /$ durum wheat & CT & $5.98 \mathrm{a}$ & 93 & 71 & $64 \mathrm{a}$ \\
& DSM & $2.95 \mathrm{~b}$ & 90 & 71 & $33 \mathrm{~b}$ \\
\hline $2007 /$ corn & CT & $13.8 \mathrm{a}$ & 218 & 203 & $63 \mathrm{a}$ \\
& DSM & $12.85 \mathrm{a}$ & 182 & 203 & $71 \mathrm{a}$ \\
\hline
\end{tabular}

Different letters above the data points represent significant differences between means $(\mathrm{P}<0.05)$.

\section{- Simulated irrigation water productivity}

o Model verification for cover crop

Water uptake of cover crop is important during the beginning period of winter. The comparison was made between the measured (with FDR CS615 sensor) and the simulated values of SWR for the layer of 0-30 cm. As can be seen in Figure 1, the PILOTE model simulates satisfactorily the $\mathrm{SWR}$ of this layer $(\mathrm{RMSE}=3 \mathrm{~mm}$ and $\underline{\mathrm{PE}}=0.946)$. Furthermore the model satisfactorily simulates the SWR during the cover crop season in 0-120 cm compared with neutron probe measurements (Fig. 2, RMSE $=15 \mathrm{~mm}$ and $\underline{P E}=0.998$ ). The model can take into account the effects of mulch on the evapotranspiration and provides an accurate SWR at sowing date of the main crop. Therefore we can use it to simulate the practice of DSM over the climatic series of 1991-2007. 


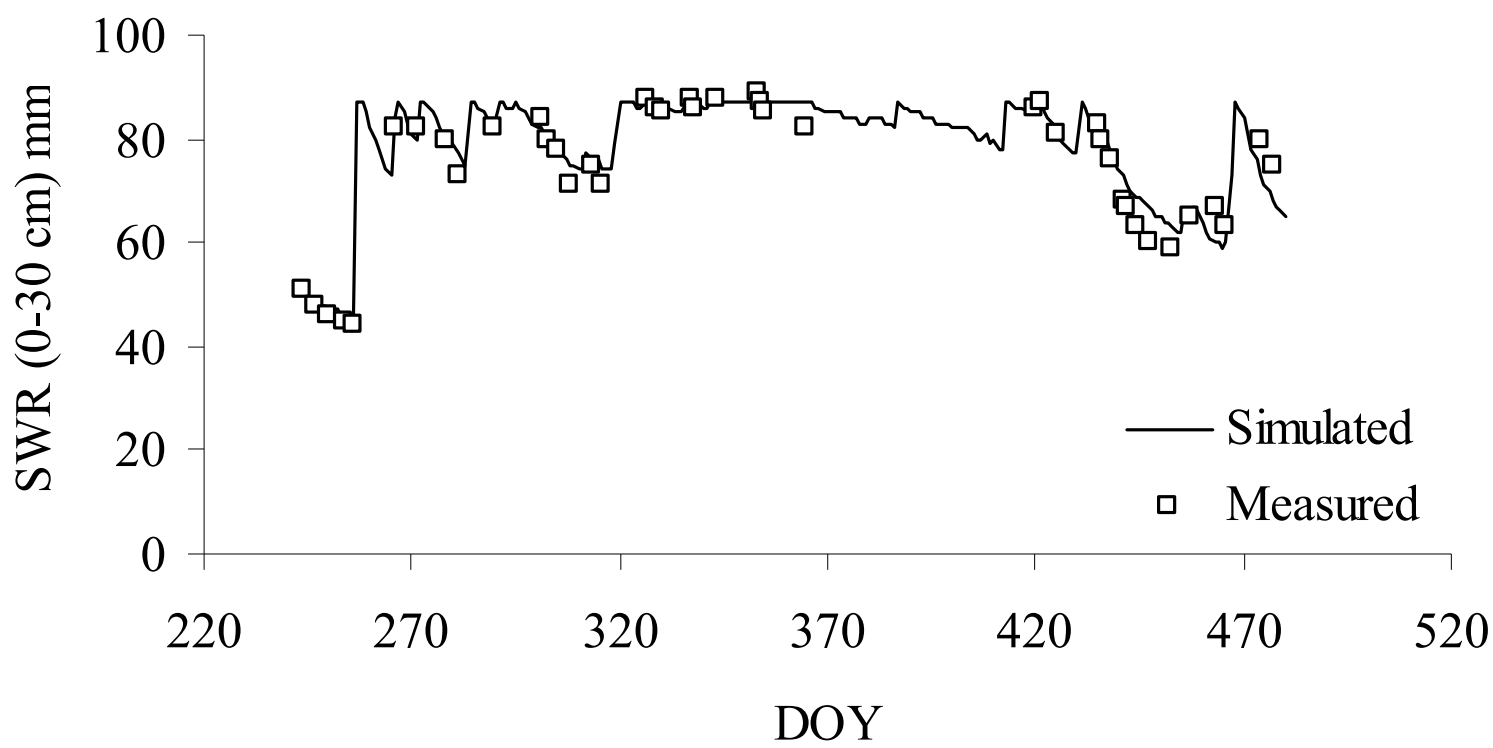

Figure 1. Simulated and measured soil water reserve (SWR; measured with FDR CS615 sensor) in DSM for the first soil layer $(0-30 \mathrm{~cm})$ with a mixed oat, vetch and rape cover crop (RMSE $=3 \mathrm{~mm}$ and $\underline{\mathrm{PE}}=0.946$; DOY: day of year)

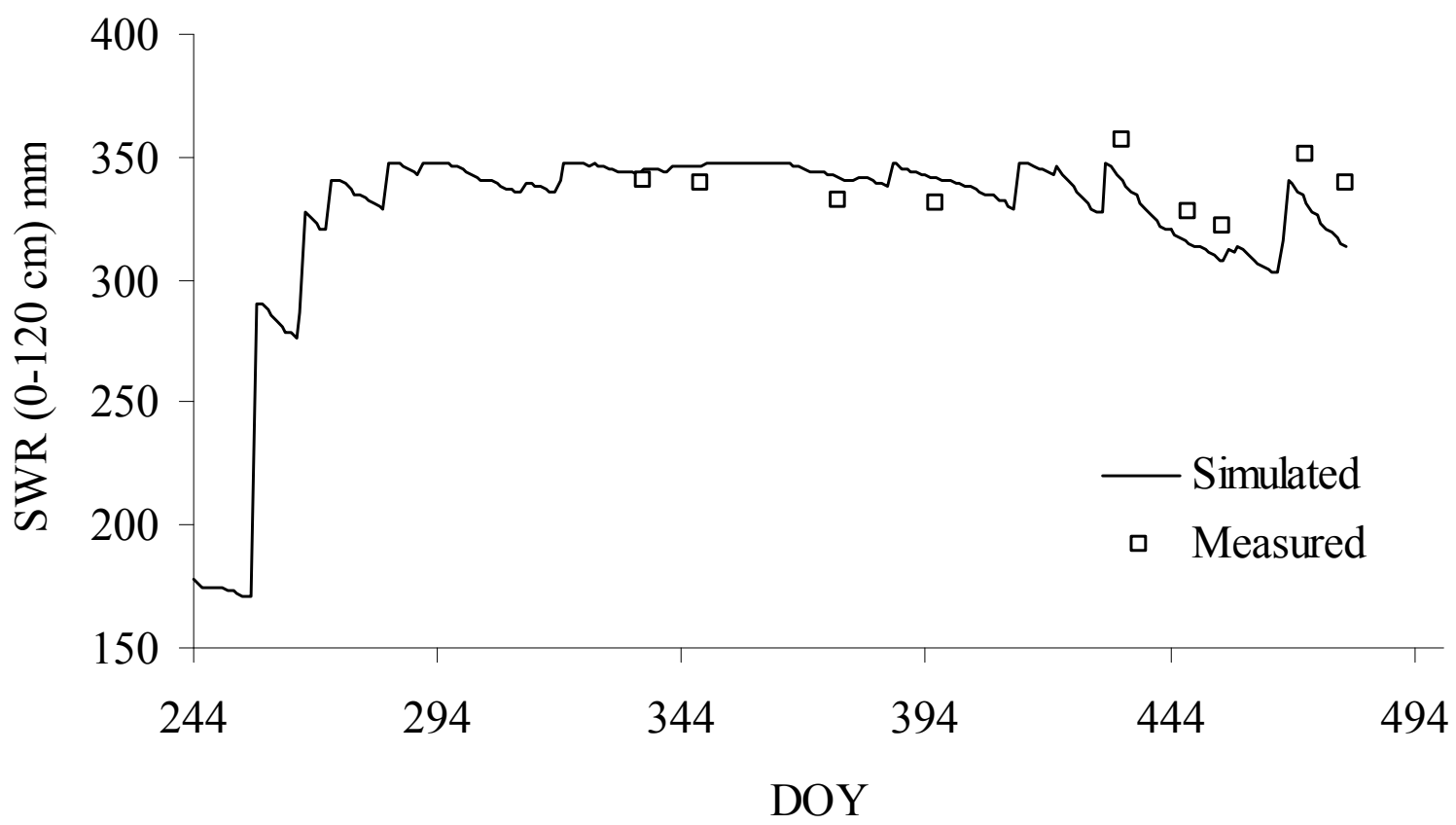

Figure 2. Simulated and measured soil water reserve (SWR; measured with neutron probe in 0-120 cm) in DSM with a mixed oat, vetch and rape cover crop (RMSE=15 $\mathrm{mm}$ and $\underline{\mathrm{PE}}=0.998$; DOY: day of year) 
o Model application on the climatic series

PILOTE simulates satisfactorily the yield and the SWR during the growth season of main crop with RMSEs of $0.87 \mathrm{Mg} / \mathrm{ha}$ and $13 \mathrm{~mm}$ for yield and SWR, respectively and the minimum PE of 0.9 for SWR (see Khaledian et al. (2009) for more details).

Table 8 presents the results of PILOTE simulations on the climatic series of 1991-2007. WP was found to increase from 77 with CT to $102 \mathrm{~kg} / \mathrm{mm}$ with DSM in the climate of Lavalette. Furthermore we can say that in average a water application depth of $40 \mathrm{~mm}$ was saved with DSM compared with CT.

Table 8. Simulation results on the climatic series of 1991-2007 at Lavalette to calculate water productivity (WP) with conventional tillage (CT) and direct seeding into mulch (DSM)

\begin{tabular}{|c|c|c|c|c|c|c|}
\hline \multirow[t]{2}{*}{ Year } & \multicolumn{3}{|l|}{ CT } & \multicolumn{3}{|l|}{$\overline{\mathrm{DDSM}}$} \\
\hline & $\begin{array}{l}\text { applied water } \\
\text { (mm) }\end{array}$ & $\begin{array}{l}\text { yield } \\
(\mathrm{Mg} / \mathrm{ha})^{*}\end{array}$ & $\begin{array}{l}\text { WP } \\
(\mathrm{kg} / \mathrm{mm})\end{array}$ & $\begin{array}{l}\text { applied water } \\
(\mathrm{mm})\end{array}$ & $\begin{array}{l}\text { yield } \\
(\mathrm{Mg} / \mathrm{ha})^{*}\end{array}$ & $\begin{array}{l}\text { WP } \\
(\mathrm{kg} / \mathrm{mm})\end{array}$ \\
\hline 1991 & 210 & 14.3 & 68 & 175 & 13.6 & 78 \\
\hline 1992 & 85 & 15 & 176 & 50 & 15.3 & 306 \\
\hline 1993 & 175 & 14 & 80 & 140 & 13.8 & 99 \\
\hline 1994 & 225 & 13.8 & 61 & 190 & 13.8 & 73 \\
\hline 1995 & 225 & 13.5 & 60 & 190 & 12.8 & 67 \\
\hline 1996 & 140 & 14.3 & 102 & 105 & 13.8 & 131 \\
\hline 1997 & 120 & 13.1 & 109 & 85 & 13.2 & 155 \\
\hline 1998 & 210 & 13.9 & 66 & 155 & 13.6 & 88 \\
\hline 1999 & 190 & 15.5 & 82 & 140 & 15.6 & 111 \\
\hline 2000 & 190 & 15.7 & 83 & 190 & 15.7 & 83 \\
\hline 2001 & 225 & 15.5 & 69 & 155 & 16 & 103 \\
\hline 2002 & 225 & 16.1 & 72 & 190 & 15.8 & 83 \\
\hline 2003 & 330 & 13.9 & 42 & 260 & 13.8 & 53 \\
\hline 2004 & 225 & 14.8 & 66 & 175 & 14.4 & 82 \\
\hline 2005 & 225 & 15 & 67 & 225 & 15.1 & 67 \\
\hline 2006 & 295 & 14.9 & 51 & 260 & 14.5 & 56 \\
\hline 2007 & 225 & 15.4 & 68 & 155 & 15.4 & 99 \\
\hline Mean & 207 & 14.6 & 77 & 167 & 14.5 & 102 \\
\hline $\mathrm{SD}^{* *}$ & 58 & 0.9 & 30 & 55 & 1 & 59 \\
\hline $\mathrm{CV}(\%)^{* * *}$ & 28 & 5.9 & 39 & 33 & 7 & 58 \\
\hline
\end{tabular}

with $15 \%$ of humidity, ${ }^{* *}$ standard deviation, ${ }^{* * *}$ coefficient of variation

There were some years where the gain in terms of water saving was worthless because of lower rainfalls after destruction of the cover crop. It is clear that by the spring rainfalls, the soil water reserve will be more or less restored at sowing of the main crop. One example for the 2006/07 season is presented in Figure 3. But water savings expected in DSM compared to CT may be lacking in some years with a dry spring. 


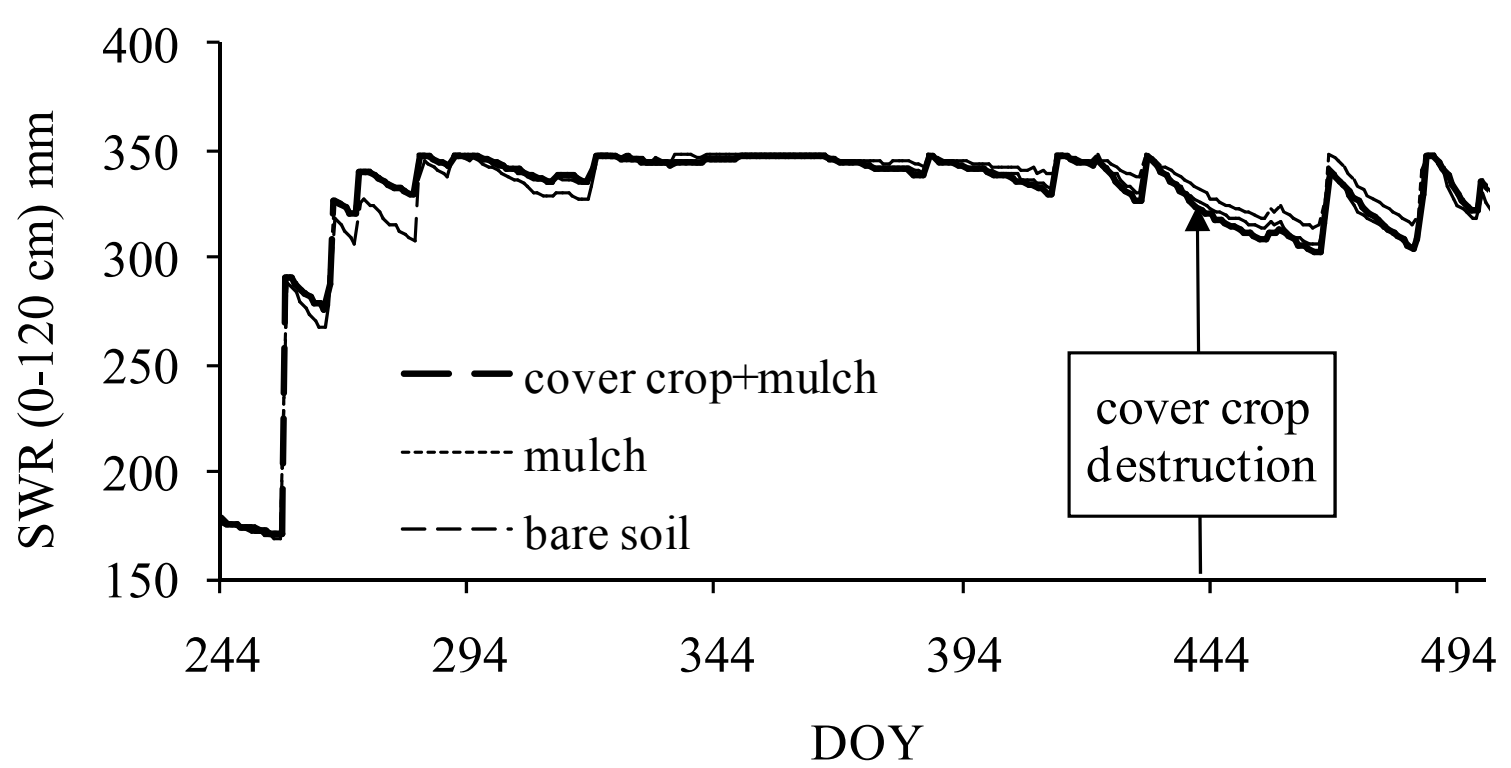

Figure 3. Simulated soil water reserve (SWR) in DSM in 0-120 cm with bare soil, soil covered by mulch and soil covered by mulch and with a mixed oat, vetch and rape cover crop in 2006/07 (DOY: day of year)

\section{Conclusion}

The present study compared the $\mathrm{N}$ balance and WP for corn, sorghum and durum wheat under DSM and CT systems. A better soil water and nutrient storage in DSM led us to hypothesis that in the Mediterranean climate with water scarcity and erratic rainfall, DSM would have a better $\mathrm{N}$ balance and WP compared with $\mathrm{CT}$.

The results showed that DSM can mitigate $\mathrm{N}$ losses which are interesting in the term of environmental protection. The experimental results also showed that DSM is able to increase $\underline{\text { WP }}$ in the Mediterranean climate and accordingly makes a contribution to address water scarcity. With the exception of the first season, when DSM was not yet installed, WP for corn and sorghum had tended to be higher; however the differences were not significant. Because of experimental limitations to check the potential of DSM to improve WP, PILOTE model was used to verify WP in DSM compared with CT. Average WP values are 77 and 102 $\mathrm{Kg} / \mathrm{mm}$ for CT and DSM, respectively. The standard variation of WP is higher with DSM. Indeed, some years DSM was not advantageous compared with CT in the term of water saving, because of lower spring rainfalls which cannot refill the soil water reserve depleted by the cover crop. It should be noted that such so high WP values were obtained assuming that all of production factors, except of water, are under optimal conditions e.g. nutrients. The results of the model during the long climatic series of 1991-2007 confirm that DSM can be more efficient in water use than CT. DSM saved in average a water application depth of 40 $\mathrm{mm}$ compared to CT system, which is interesting in a context characterized by water scarcity. It can be said that after some years of DSM practices at Lavalette, $\mathrm{N}$ losses mitigated compared with CT, being interesting in the term of environmental protection. There are some models simulating well, more or less, the $\mathrm{N}$ balance in $\mathrm{CT}$. But, efforts are still required to obtain acceptable results under DSM where the microorganisms play a major role in the $\mathrm{N}$ fate mainly due to the $\mathrm{N}$ release phenomenon. The results derived from this experimental analysis can contribute to improve the existing models. 


\section{Acknowledgement}

I would like to express my gratitude to our technicians: P. Rosique, L. Delage and G. Lannes to do the necessary research works.

\section{Reference}

Angás P, Lampurlanés J, Cantero-Martínez C (2006) Tillage and N fertilization: Effects on N dynamics and Barley yield under semiarid Mediterranean conditions. Soil Till Res 87: 59-71

Aulakh MS, Rennie DA (1984) Transformation of autumnapplied nitrogen-15-labeled fertilizers. Soil Sci Soc Am J 48: 1184-1189

Bertocco M, Basso B, Sartori L, Martin EC (2008) Evaluating energy efficiency of sitespecific tillage in maize in NE Italy. Bioresour Technol 99: 6957-6965

Bhagat RM, Verma TS (1991) Impact of rice straw management on soil physical properties and wheat yield. Soil Sci 152: 108-115

Bussière F, Cellier P (1994) Modification of the soil temperature and water content regimes by a crop residue mulch: experiment and modelling. Agr Forest Meteorol 68: 1-28

Campbell CA, Zentner RP, (1993) Soil Organic Matter as Influenced by Crop Rotations and Fertilization. Soil Sci Soc Am J 57: 1034-1040

Cannel RQ (1985) Reduced tillage in north-west Europe: a review. Soil Till Res 5: 129-177

Creus CJ, Studdert GA, Echeverría HE, Sanchez SR (1998) Descomposición de residuos de cosecha de maíz y dinámica del nitrógeno en el suelo. Ciencia del suelo 16: 51-57

Dahiya R, Ingwersen J, Streck T (2007) The effect of mulching and tillage on the water and temperature regimes of a loess soil: Experimental findings and modeling. Soil Till Res 96: $52-63$

de Fraiture C, Wichelns D, Kemp Benedict E, Rockstrom J (2007) Scenarios on water for food and environment. In: Molden D (ED), Water for Food, Water for Life: A Comprehensive Assessment of Water Management in Agriculture, Chapter 3, Earthscan, London and International Water Management Institute, Colombo, pp 91-145

De Vita P, Di Paolo E, Fecondo G, Di Fonzo N, Pisante M (2007) No-tillage and conventional tillage effects on durum wheat yield, grain quality and soil moisture content in southern Italy. Soil Till Res 92: 69-78

Delin S, Lindén B (2002) Relations between net nitrogen mineralization and soil characteristics within an arable soil. Acta Agr Scand B-S P 52(2-3): 78-85

Derpsch R (2005) The extent of conservation agriculture adoption worldwide: implications and impact, Proceedings 3rd World Congress on Conservation Agriculture Nairobi

Deumlich D, Funk R, Frielinghaus M, Schmidt WA, Nitzsche O (2006) Basics of effective erosion control in German agriculture: a review. J Plant Nutr Soil Sc 169: 370-381

Doran J (1980) Soil microbial and biochemical changes associated with reduced tillage. Soil Sci Soc Am J 44: 765-771

FAO (2009) http://www.fao.org/ag/ca/

Findeling A, Ruy S, Scopel E (2003) Modeling the effects of a partial residue mulch on runoff using a physically based approach. J Hydrol 275: 49-66

Franzluebbers AJ, Francis CA (1995) Energy output: input ratio of maize and sorghum management systems in eastern Nebraska. Agric Ecosyst Environ 53 (3): 271-278

Gonzalez-Sosa E, Braud I, Thony IJL, Vauclin M, Bessemoulin P, Calvet JC (1999) Modelling Heat and water exchanges of fallow land covered with plant-residue mulch. Agr Forest Meteorol 97: 151-169 
Govaerts B, Fuentes M, Mezzalama M, Nicol JM, Deckers J, Etchevers JD, FigueroaSandoval B, Sayre KD (2007) Infiltration, soil moisture, root rot and nematode populations after 12 years of different tillage, residue and crop rotation managements. Soil Till Res 94: 209-219

Gusev E (2002) The technique of assessment of impact of mulching soil by plant remains on formation of water regime and yield of agricultural ecosystems. Water Problem Institute, Russian Academy of Sciences, In third international conference on water resources and environmental research, Dresden (Germany) 22-25 July 2002: 168-172

Holland JM (2004) The environmental consequences of adopting conservation tillage in Europe: Reviewing evidence. Agr Ecosyst Environ 103: 1-25

Kalra N, Sarma KSS, Nagarajarao Y (1984) Modification of hydro-thermal regimes by the application of residue mulch for better water use, root growth and yield of summer mungbean. Transactions of Indian Society of Desert Technology and University Centre of Desert Studies 9(2): 68-71

Khaledian MR (2009) Evaluation de la technique du semis direct en culture irriguée en comparaison avec le système de culture conventionnel. Dissertation, University of Montpellier II

Khaledian MR, Mailhol JC, Ruelle P, Rosique P (2009) Adapting PILOTE model for water and yield management under direct seeding system: The case of corn and durum wheat in a Mediterranean context. Agr Water Manage 96: 757-770

Lahmar R (2008) Adoption of conservation agriculture in Europe: Lessons of the KASSA project. Land Use Policy. Doi: 10.1016/j.landusepol.2008.02.001

Linn DM, Doran JW (1984) Aerobic and anaerobic microbial populations in no-till and plowed soils. Soil Sci Soc Am J 48: 794-799

Mailhol JC, Olufayo AA, Ruelle P (1997) Sorghum and sunflower evapotranspiration and yield from simulated leaf area index. Agr Water Manage 35: 167-182

Mailhol JC, Zaïri A, Slatni A, Ben Nouma B, El Amami H (2004) Analysis of irrigation systems and irrigation strategies for durum wheat in Tunisia. Agr Water Manage 70: 1937

Malhi SS, Grant CA, Johnston AM, Gill KS (2001) Nitrogen fertilization management for notill cereal production in the Canadian Great Plains: a review. Soil Till Res 60(3-4): 101122

Mary B, Recous S, Darwis D, Robin D (1996) Interactions between decomposition of plant residues and nitrogen cycling in soil. Plant Soil 181: 71-82

Montemurro F, Maiorana M, Ferri D, Convertini G (2006) Nitrogen indicators, uptake and utilization efficiency in a maize and barley rotation cropped at different levels and sources of N fertilization. Field Crop Res 99: 114-124

Nash JE, Sutcliffe JV (1970) River flow forecasting through conceptual models Part 1. A discussion of principles. J Hydrol 10: 282-290

Nemeth I (2001) Pollution azotée sous irrigation gravitaire: caractérisation de l'effet des pratiques agricoles et proposition d'amélioration. Application au cas d'un périmètre irrigué du Mexique. Dissertation, University of Montpellier II

Nyborg M, Malhi SS (1989) Effect of zero and conventional tillage on barley yield and NO3$\mathrm{N}$ content, moisture and temperature of soil in north-central Alberta. Soil Till Res 15: 19

Paustian K, Andrén O, Clarholm M, Hansson AC, Johansson G, Lagerlöf J, Lindberg T, Pettersson R, Sohlenius B (1990) Carbon and nitrogen budgets of four agro-ecosystems with annual and perennial crops, with and without $\mathrm{N}$ fertilization. J Appl Ecol 27(1): $60-84$ 
Postel S (1989) Water for Agriculture: Facing the Limits. Worldwatch Report 93. Worldwatch Institute

Rasmussen KJ (1999) Impact of ploughless soil tillage on yield and soil quality: a Scandinavian review. Soil Till Res 53: 3-14

Rice CW, Smith MS (1982) Denitrification in no till and plowed soils. Soil Sci Soc Am J 46: 1168-1173

Rice CW, Smith MS, Blevins RL (1986) Soil nitrogen availability after long-term continuous no-tillage and conventional tillage corn production. Soil Sci Soc Am J 50: 1206-1210

Rodrigues GC, Pereira LS (2009) Assessing economic impacts of deficit irrigation as related to water productivity and water costs. Biosystems engineering 103(4): 536-551

Ross PJ, Williams J, McCown RL (1985) Soil temperature and the energy balance of vegetative mulch in the semi-arid tropics: II. Dynamic analysis of the total energy balance. Aust J Soil Res 23: 515-532

Schroth G, Salazar E, Da Silva JJP (2001) Soil Nitrogen Mineralization under Tree Crops and a Legume Cover Crop in Multi-Strata Agroforestry in Central Amazonia: Spatial and Temporal Patterns. Exp Agr 37: 253-267

Scopel E (1994) Le semis direct avec paillis de résidus dans la région de V. Carranza au Mexique: Intérêt de cette technique pour améliorer l'alimentation hydrique du mais pluvial en zones à pluviométrie irrégulière. Dissertation, Institut Agronomique de Paris Grignon

Scopel E, Macena F, Corbeels M, Affholder F, Maraux F (2004) Modelling crop residue mulching effects on water use and production of maize under semi-arid and humid tropical conditions. Agronomie 24: 1-13

Sexton BT, Moncrief JF, Rosen CJ, Gupta SC, Cheng HH (1996) Optimizing nitrogen and irrigation inputs for corn on nitrate leaching and yield on a Coarse-Textured soil. $\mathrm{J}$ Environ Qual 25: 982-992

Soane BD, Ball BC (1998) Review of management and conduct of long-term tillage studies with special reference to a 25-yr experiment on barley in Scotland. Soil Till Res 45: 1737

Tebrügge F, Düring RA (1999) Reducing tillage intensity: a review of results from long-term study in Germany. Soil Till Res 53: 15-28

Unger PW (1991) Organic matter, nutrient, and $\mathrm{pH}$ distribution in no- and conventionaltillage semiarid soils. Agron. J. 83: 186-189

Viets FGJr (1962) Fertilizers and the efficient use of water. Adv Agron 14: 223-264 